\title{
Review on Influence of Climate Alterations on Corals and Associated Fishes for Indian Scenario
}

Uthaya Siva $\mathbf{M}^{*}$, Selvakumar $\mathbf{P}$ and Sakthivel $\mathbf{A}$

CAS in Marine Biology, Faculty of Marine Science, Annamalai University, Parangipettai-608502, India

\begin{abstract}
Global warming is progression in which the earth temperature and the temperature on the atmosphere layers that are close to earth rise artificially as a result of the intense increase in some gases that occur in consequence of various human activities and that are qualified as greenhouse gases in the atmosphere. As to global climate change, it is the phenomenon where other climatic factors change as well depending upon global warming. Marine ecosystems are not in a steady state, but are affected by the environment, which varies on many spatial and temporal scales. Generally due to climate change and global warming the small and beneficial microorganism such as algae, bacteria, phyto and zooplanktons are getting disturbed or due to increasing of temperature and sea level raise it powerless to survive in the water surroundings. Detailed information is reported on the main Indian reef areas, including the Lakshadweep Islands, Andaman and Nicobar Islands, and Gulf of Mannar, with limited and largely anecdotal information for reefs elsewhere in the country. A fish population cannot be tolerant of high temperature changes in the area where it is distributed in a certain time interval. If these changes are within a certain temperature boundary and slow, it generally causes migration of fish specifically ornamental clown fishes. Temperature takes important physiological phenomena such as feeding, respiration, osmoregulation, growth and reproduction under control. If the individuals of population cannot adjust themselves according to the sudden and strong changes in temperature, one or some of their metabolism activities may deteriorate and mass deaths may occur and the changes in the sea water level will endanger the coastal habitat and species such as the sea turtle which uses the beaches as reproduction areas and lays eggs there will be unfavorably affected since their reproduction areas will become narrower.
\end{abstract}

Keywords: Climate Alterations, Osmoregulation, Global warming, Marine ecosystems, Temperature

\section{Introduction}

Now it is widely accepted statement that the climate change is no longer simply a potential threat, it is unavoidable; a consequence of 200 years of Excessive Greenhouse Gas (GHG) emissions from fossil fuel combustion in energy generation, transport and industry, deforestation and intensive agriculture [1]. IFAD and other development agencies have recognized the climate change as one the greatest threats facing mankind today $[2,3]$ and tomorrow, it's have highlighted fact, that the poorest and most vulnerable will be disproportionately affected by the impacts of global warming [4]. Its defines the process in which the earth's temperature and temperature on the atmosphere layers that are close to earth rise artificially as a result of the intense increase in some gases that occur in consequence of various human activities and that are qualified as greenhouse gases in the atmosphere of Earth. As to global climate change, it's the major phenomenon where other climatic factors were changed as well depending upon global warming. Tekinayve Guroy clarified that Oceans and sea waters are mostly affected by the process of climate change instigated by global warming. Since they constitute a large portion of our planet and have rich biodiversity of copious of organisms. A temperature have increased only a few degrees does not only because an increase in the temperature of large water masses such as oceans, seas, lakes, and ponds but it also causes hydrological events that cause a change in the physical and chemical characteristics of water. Water temperature is the most important environmental parameter that affects the life cycle, physiology and behaviors of aquatic living beings [5]. With global warming, the waters of oceans are also warming up though there are considerable variations in different geographical regions and at different times. Warming has been more intense in surface waters, and there are evidences for deep water warming too. The world's oceans are also affected by changes in precipitation, wind and currents, which are the result of geographical differences in temperature and humidity of the atmosphere. Thus, important oceanic weather systems such as the El Nino Southern Oscillation (ENSO) and Indian Ocean monsoon will be affected by global warming. Other direct effects of warming on aquatic systems include changes in precipitation, evaporation, river flows, groundwater, lakes and sea levels. These changes have altered the energy balance in the atmosphere, resulting in a warming effect. Later, Kennedy et al. described that Marine ecosystems are not in a steady state, but are affected by the environment, which varies on many spatial and temporal scales. Generally due to climate change and global warming the small and beneficial microorganism such as algae, bacteria, phyto and zooplanktons are getting disturbed or due to increasing of temperature it unable to survive in the water environment. These beneficial microbes are playing a vital role in the form of primary production in the ecosystem by which the fishes and other organisms getting feed. Changes in temperature are related to alterations in oceanic circulation patterns that are affected by changes in the direction and speed of the winds that drive ocean currents and mix surface waters with deeper nutrient rich waters. These processes in turn affect the distribution and abundance of plankton, which are food for small fish [6]. Hoegh-Guldberg et al. reported that Coral reefs are highly diverse and economically important to approximately

${ }^{*}$ Corresponding author: Uthaya Siva M, Ph.D., Research Scholar, CAS in Marine Biology, Faculty of Marine Science, Annamalai University, Parangipettai-608502, India, Tel: +91 9994992532; E-mail: uthayasiva.m1@gmail.com

Received July 10, 2014; Accepted August 11, 2014; Published August 25, 2014

Citation: Uthaya Siva M, Selvakumar P, Sakthivel A (2014) Review on Influence of Climate Alterations on Corals and Associated Fishes for Indian Scenario. J Climatol Weather Forecasting 2: 114. doi:10.4172/2332-2594.1000114

Copyright: @ 2014 Uthaya Siva M, et al. This is an open-access article distributed under the terms of the Creative Commons Attribution License, which permits unrestricted use, distribution, and reproduction in any medium, provided the original author and source are credited. 
100 million people in the tropics, yet their future is being threatened by rapid climate change [7]. Sutherland et al. stated that Identifying and prioritizing management of coral reefs in areas of lowclimate stress or reefs that are resilient to climate change is a leading rationale for informing the placement and implementation of challenging management interventions, such as no-take or closed areas [8]. The current status of coral reefs, coral reef research and Government policy towards conservation and management of reefs in India. Vineeta Hoorn reviewed more recent information is cited as available and analyzed to show the most recent trends in resource condition, use and conservation [9]. Due to global warming followed by sea level rise is more dangerous to affect coral reefs. When the corals are affected continually followed by the associated organisms such as fishes, mollusk, and warms are getting eradicated from ecosystem.

\section{Macroalgae (Seaweeds, Sea grass and Coral reef)}

Schaffelke et al. and Ritson-Williams et al. explained Macroalgae is a collective term used for seaweeds and other benthic marine plants that are generally visible to through naked eye. Seaweeds and sea grass are broadly comprise species from three different phyla, Rhodophyta (red algae), Heterokontophyta (predominantly Phaeophyceae, the brown algae), and Chlorophyta. They are clearly distinguished from microalgae, which require an associate microscope to be observed as phytoplankton, benthic and pelagic diatoms, free-living din flagellates, cyanobacteria (blue-green algae) and the symbiotic zooxanthellae that live within coral tissue. In some cases, benthic microalgae, such as some cyanobacteria and Chrysophyta, form large colonies that resemble thalli of Macroalgae. Such colony-forming cyanobacteria are often common components of turf algal assemblages [10,11]. Coral reefs are very important organisms living in the sea sores and zooxanthellae are occupied the tissue allthe corals and coral polyps as well with a symbiotic relationship. More than $90 \%$ of the corals gettingenergy come from the associate zooplankton of zooxanthellae, so corals are extremely dependent on symbiotic relationship of zooxanthellae. Coral bleaching will occurs when the coral host ejects zooxanthellae. Photosynthetic pigments are come from zooxanthellae and its gives colour. Therefore, the tissue of the coral appears transparent and the coral's bright white skeleton is revealed.

\section{Marine Ornamental Fish}

Dey and Ajit Kumar et al. defined as Ornamental fishes can be consider as an attractive in world over with colourful fishes of peaceful nature that are kept as pets in confined spaces of an aquarium or a garden pool with the purpose of enjoying their beauty for fun and fancy and those are visually exciting objects $[12,13]$. Because of they may have unique shapes, colouration, body forms and movements. Ornamental fishes are also called 'living jewels' for their beautiful colours and playful behavior. Ornamental fishes are typically small sized, colorful and most often bizarre shaped in appearance [13]. However, these fishes need not necessarily be always colorful. In fact, certain Fish species loved by aquarist are quite ugly; in such cases the peculiar appearance is a source of attraction for the aquarium lovers and naturalist [14], with the inspiring popularity of aquarium keeping in households in many parts of the world, ornamental has become an important part in international trade.

The world trade of ornamental fish is one of the most valued at about US \$ 9.0 billion (FAO 2004). In Indian domestic trade in ornamental fish is conservatively estimated at Rs. 10 crores. It is growing at the rate of 20 percent annually and the present domestic demand is higher than the supply [15]. Ornamental fish trade was increasing frequently because of demand. This is the main reason of collecting marine ornamentals from the wild, so few years afterward the biodiversity will be totally eradicate due to overfishing so now very necessary to produce hatchery bred for conserve the natural stock. In natural conditions, plenty of foods of different types are available to suit the requirements of different fishes living in a particular environment. Aquarists have a great role in learning and understanding nature, especially aquatic life. Coral reef fishes (also called clown fishes and anemone fishes) are members of the family, Pomacentridae; subfamily Amphiprioninae. Among the commercially traded families of reef fishes, Pomacentridae dominate, accounting for nearly $43 \%$. The damsels contain approximately 235 species worldwide [16]. They are unique because all of the species have an obligate symbiotic relationship with sea anemones [17], formation of a group consisting monogamous pairs and protandrous hermaphrodites [18]. Anemone fishes are one of the most popular and best marine ornamental fishes and have been bred successfully in captivity [19]. Among freshwater ornamental fishes, around $90 \%$ are farmed and reproduced while $10 \%$ are collected from the wild, but in the case of marine ornamental fish, more than $95 \%$ is collected from the wild [20]. Ajith Kumar et al. reported the commercially important marine ornamental fishes are clowns, damsels, angels, wrasses, butterflies and sea horses [13]. Sale stated most coral reef fish species disperse widely as pelagic larvae but after settling to a reef, they adopt a much more sedentary habit within a small territory [21]. Booth and Wellington demonstrated that habitat preferences of these fishes match well with their effects on subsequent survival, growth and reproduction [22]. Coral reef fishes are very sensitive to accumulate in the marine ecosystem and corals as well. If the corals are getting bleached automatically the associate fishes will go away. So it's very much necessity to study the corals and marine ornamental fishes as well.

\section{Coral Reefs Ecosystem in South Asia}

Previous reports are demonstrating that Climate changes are the main regional threat to coral reefs in the sea sores of South Asia. Effects from higher temperature are more variable precipitation; more extreme weather events. Sea level rise are already being felt in South Asia and it is increasing gradually. Due to this fact the coastal peoples are affecting all the years. A reduction in calcification rates caused by rising of ocean acidification may be equally severe or even more so. However, reefs are also facing severe straight human stresses from over-fishing as well as destructive fishing, coastal development, runoff from land and increased sedimentation. These are the main drivers of reef degradation as well as coral bleaching: areas where human effect and use of reef resources has been minimal are presently comparatively healthier (e.g. Chaos and around the Jaffna Peninsula in northern Sri Lanka) than other areas. Poor management of coastal areas, including many MPAs and NGOs, as well as intensive reef resource use, remains a concern in all countries [23]. Coastal and marine ecosystems are the main resources providing large benefits to the countries of the region through fisheries and tourism, which are highly important economic sectors in the Maldives, India and Sri Lanka. Many people throughout the region are directly dependent on reef and fisheries resources, however, poverty is widespread, especially among coastal populations (which are also dependent on other natural resources). Moreover the millions of peoples rely heavily on coastal and marine ecosystems and resources for employment, income, and food protein [23]. For example, in the Andaman Nicobar and Lakshadweep Islands as much as $90 \%$ of the protein intake for poor households comes from reef fishing and 
gleaning from the Arabian Sea and Bay of Bengal. Not only because of fisheries, at the same time is the tourism also the important factors to improve the economic status of the country as well as coastal peoples.

\section{Coral Reefs Ecosystem in India}

The detailed information was reported on the main Indian reef beds, including the Lakshadweep Archipelago, Andaman and Nicobar Islands, and Gulf of Mannar, with limited and largely anecdotal information for corals elsewhere in the country (Figure 1). The patterns of coral reefs recovery are described previously as continuing in the Lakshadweep Archipelago with coral cover was increased at the most of the coral reef sites. Recovery is faster on west-facing than eastern sites, largely due to differences in settlement patterns and substrate stability in the sea sores. There has been a reduction in algal turf and macro-algal cover compared to earlier studies, possibly explained by healthy populations of algal eating fish, particularly scarids and acanthurids, which are reported to facilitate coral recovery in the sea sores. The former dominant Acropora species, such as A. abrotanoides, are returning to dominance. An increase in coral bleaching at levels higher than normal summer bleaching was observed in April 2007; the extent and mortality is not known but appears to be limited. The impact of the 2004 tsunami was examined in detail on the Andaman and Nicobar Islands in 2005 and 2006. More than $100 \mathrm{~km}$ of shallow reef area was damaged in the Andaman Islands with most of this due to tectonic uplift and aerial exposure, as well as by the tsunami waves carving channels between islands. Many reef areas, especially in the Andaman Islands, were moderately to slightly affected and coral cover remains between 30 and $70 \%$. A significant reduction in coral cover occurred at North Reef, Northern Andaman, and Interview Island, Middle Andaman. More than $200 \mathrm{~km}$ of reef was damaged in the Nicobar Islands due to tectonic activity, the tsunami and consequent sedimentation. Subsidence of the islands changed beach profiles and high erosion and sedimentation continued for more than 8 months after the tsunami. Severe damage in these areas extended to more than $20 \mathrm{~m}$ depth. Diversity of hermatypic corals in the Indian Ocean is present in the Figure 2. Coral cover at Car Nicobar is now about $5 \%$ after suffering more than $90 \%$ mortality [23]. Good coral larval recruitment has been reported from the Andaman Islands, while in the Nicobars it remains negligible. In some parts of the Nicobar Islands hard corals are facing competition from soft corals.

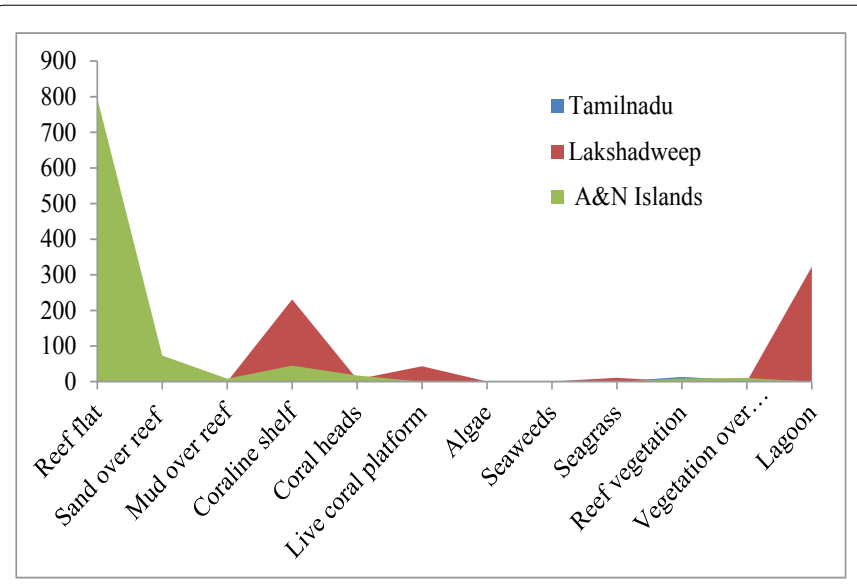

Figure 1: Area Estimates of Coral Reefs in the Country $(\mathrm{Km} 2)$ in three regions of Indian Ocean [28].

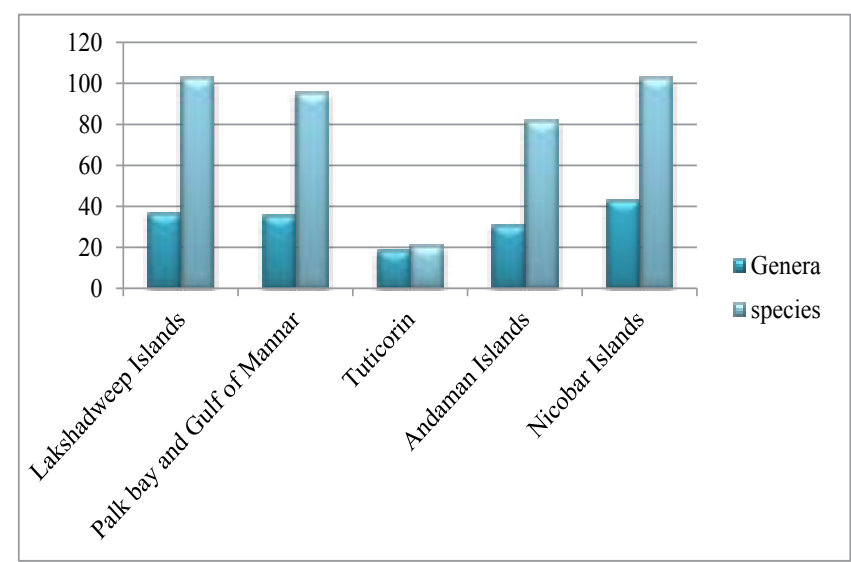

Figure 2: Diversity of hermatypic corals in the Indian Ocean [28].

\section{Coral Reefs Ecosystem in Tamilnadu:}

Vineeta Hoon stated that coral reefs in the Tamil Nadu coast are available to see with naked eye at Palk Bay near Rameshwaram and in the Gulf of Mannar. Palk Bay is the place separated from the gulf of Manner by Mandabam peninsula and Rameshwaram Island. The reef is centered on $9^{\circ} 17^{\prime} \mathrm{N}$ and $79^{\circ} 15^{\prime}$. There is only one fringing reef in the Palk bay, which lies in an east-west direction along the mainland from the Pamban channel at the Pamban end of the bridge to Rameshwaram Island. This reef is $25-30 \mathrm{~km}$ long, and generally less than $200 \mathrm{~m}$ wide; maximum depth is around $3 \mathrm{~m}$. Visibility is poor around 1 meter and it is badly affected by the north east monsoon. The reef flat is relatively broad from Pamban channel to the southern end near Ramnad and narrow from Pamban to south of Rameshwaram. Diversity in the Palk bay reef consists of common sea grasses, sixty five species of coral have been recorded with a large number in the family Acroporidae. Turtles and Dugongs are found in the area. Squid breeding grounds occur near Rameshwaram [9]. In presently the nowadays reef growth is poor and it is not in a pristine condition since it was quarried in the sixties [24]. Satellite data shows that the reef flat is barren and is followed by sandy beach on the landward side. A small patch of reef fringes at the Dhanushkodi tip [25]. The Gulf of Mannar reefs on the other hand are developed around a chain of 21 islands that lie along the $140 \mathrm{~km}$ stretch between Tuticorin and Rameshwaram [26]. These islands are located between latitude $8^{\circ} 47^{\prime} \mathrm{N}$ and $9^{\circ} 15^{\prime} \mathrm{N}$ and longitude $78^{\circ} 12^{\prime} \mathrm{E}$ and $79^{\circ} 14^{\prime} \mathrm{E}$. A detailed account of each Island is provided by Krishnamurthy and Deshmukh and Venkatramani (1995). The islands lie at an average of about $8 \mathrm{~km}$ from the main land. They are a part of the Mannar Barrier reef which is about $140 \mathrm{~km}$ long and $25 \mathrm{~km}$ wide between Pamban and Tuticorin [27]. Different types of reef forms such as shore platform, patch, coral pinnacles and atoll type are also observed in the Gulf of Mannar. The islands have fringing coral reefs and patch reefs around them. Narrow fringing reefs are located mostly at a distance of 50 to $100 \mathrm{~m}$ from the islands. On the other hand patch reefs arise from depths of 2 to $9 \mathrm{mt}$ and extend to 1 to $2 \mathrm{~km}$ in length with width as much as 50 meters. Reef flat is extensive in almost all the reefs in the Gulf of Mannar. Reef vegetation is richly distributed on these reefs. The total area occupied by reef and its associated features is $94.3 \mathrm{sq} \mathrm{km}$. Reef flat and reef vegetation including algae occupies 64.9 and $13.7 \mathrm{sq} \mathrm{km}$, respectively [28]. Visibility is affected by monsoons, coral mining and high sedimentation load. The reefs are more luxuriant and richer than the reefs of Palk bay. Presently Pillai presents an overview of the status of coral reefs in Mannar and the 
Citation: Uthaya Siva M, Selvakumar P, Sakthivel A (2014) Review on Influence of Climate Alterations on Corals and Associated Fishes for Indian Scenario. J Climatol Weather Forecasting 2: 114. doi:10.4172/2332-2594.1000114

Page 4 of 5

species diversity [24,29-31]. His publication [29] cites the example of Manali Island in the Gulf of Mannar, and lucidly presents the situation in the gulf before the 1960's coral mining activities and the situation after the mining had taken place. He feels that coral growth in the Gulf of Mannar will be irretrievably stunted since the bottom is sandy and the planulae will not be able to settle [24]. Recent underwater surveys conducted by Kumaraguru are more encouraging [32]. They reveal that there is luxuriant coral growth around the Manali Island and that the overall condition of the reef patches in the Gulf of Mannar is not too alarming.

\section{The Impacts of Global Warming and Climate Change on Coral Ecosystem}

The effects of the global warming has created and will probably create on aquatic ecosystem can be listed as increase in water temperature and drying of the lakes, regression of glaciers, increase in the sea level, degradation in coastal ecosystem, change in precipitation amounts and models, change in the frequency and density of extreme weather phenomena, change in streams, increase in the extinction of species, increase in the distribution areas of ailment vectors, coral bleaching, and coral corruption. The main impact of global warming and climate change will be seen on coasts and also the sea sores, the most productive areas of seas. Experts conducting studies on coasts have calculated that each rise of one $\mathrm{cm}$ in the sea level may cause a horizontal regression with a width of $1 \mathrm{~m}$ on sandy coastal lines due to erosion [32] and sue to this fact the corals are unable to get sunlight. The changes in the sea water level will endanger the coastal habitat and species such as the sea turtle which uses the beaches as reproduction areas and lays eggs there will be unfavorably affected since their reproduction areas will become narrower. Mainly the associated organisms are product the corals from the predators and both are maintaining a symbiotic relationship between corals and associates, so when the symbolism is damage automatically the total ecosystem will damage.

\section{The Impacts of Global Warming and Climate Change on Fisheries}

Water temperature comes of the first in the list of most determinant factors since it is essential for the reproduction of ornamentals fishes which was being nearby corals and the formation of an ideal living environment. Fish population can be tolerant of temperature changes in the area where it is distributed in a certain time interval. If these changes are within a certain temperature boundary and slow, it generally causes migration of fish population to other reef areas. So automatically the environment will come an end. Temperature takes important physiological phenomena such as feeding, respiration, osmoregulation, growth and reproduction under the control. If the individuals of population cannot adjust themselves according to the sudden and strong changes in the temperature, one or more of their metabolism activities may deteriorate and mass deaths may occur. If long term temperature increases are observed in a region, in any stock that is prevalent in that areas, shifting of the southern border of the ovulation area towards the north, changing of ovulation areas horizontally with any increase in the bottom water temperature, preference of northern latitudes as new areas of feeding and growth, increase in food salts and amounts with the increase in temperature on higher latitudes and changes in the present currents, prolongation of the growth period in a year, and shifting of the limit within which larvae may live towards northern latitudes may be observed [33]. Graeme Mac fadyen and Edward Allison reviewed that Countries such as Russia, Peru and Columbia are sensitive to climate changes due to their high catches and reliance on exports or high employment from fisheries, but their larger economies and higher human development indices mean they are likely to have a higher adaptive capacity to deal with potential impacts [34].

\section{References}

1. IPCC (2007) Climate Change 2007: The Physical Science Basis. Summary for Policymakers. Intergovernmental Panel on Climate Change 18.

2. IFAD (2007) IFAD Strategic Framework 2007-2010. IFAD, Rome, Italy, 35 pp.

3. World Bank (2010) World Development Report 2010: Development and Climate Change. The World Bank, Washington, DC, USA, 424 pp.

4. IFAD (2008) Climate Change: A Development Challenge. IFAD, Rome, Italy, $4 \mathrm{pp}$.

5. Tekinay $A$, veGüroy $D(2007)$ ĐklimdeğiikliğiTürkiyebalıküretimininasıletkileye cek? I.TürkiyeDklimDeğiikliğiKongresi, BildirilerKitabı: 329-334. 11-13 Nisan 2007, Đstanbul.

6. Kennedy VS, RR Twilley, JA Kleypas, JH Cowan Jr and SR Hare (2002) Coastal and marine ecosystems and global climate change. Pew Center on Global Climate Change, Arlington, USA, $52 \mathrm{pp}$.

7. Hoegh-Guldberg O, Mumby PJ, Hooten AJ (2007) Coral reefs under rapid climate change and ocean acidification. Science, 318, 1737-1742.

8. Sutherland WJ, Adams WM, Aronson RB (2009) Conservation Biology, ENFA and regression-kriging. Ecological Modeling, 220, 3499-3511. 23, 557-567.

9. Hoon V, Sriskanathan G, Townsley P, Cattermoul B (2008) Socioeconomic Monitoring Guidelines for Coastal Managers of South Asia, SocMon South Asia IUCN/CORDIO.

10. Schaffelke B, Heimann K, Marshall PA, Ayling AM (2004) Blooms of Chrysocystis fragilis on the Great Barrier Reef. Coral Reefs 23:514

11. Ritson-Williams R, Paul VJ, Bonito V (2005) Marine benthic cyanobacteria Overgrow coral reef organisms. Coral Reefs 24:629

12. Dey, VK (1996) Ornamental fishes and Handbook of Aqua farming. The Marine Products Export Development Authority, Cochin.

13. Ajith Kumar T T, Marudhupandi T, Balamurugan J \& Balasubramanian T (2012) Clown fish (Amphiprion sandaracinos, (Allen, 1972) and A. melanopus (Bleeker 1852)). Success in Hatchery Seed Production by the Centre of Advanced Study in Marine Biology, Annamalai University. Fishing Chimes32 (3).

14. Abhisek basu, Dibyendu dutta and Samir banerjee (2012) Indigenous ornamental fishes of west bengal. Recent research in science and technology 2012, 4(11): 12-21

15. Threatened freshwater fishes of India (2010) and IUCN, 2011.

16. Allen GR (1991) Damsel fishes of the world, Mergus publishers, Mello, Germany. pp: 271.

17. Fautin D G and Allen G R (1997) Anemone fishes and their host sea anemones Western Australian Museum 160.

18. Ross R M (1978) Territorial behaviour and ecology of the anemone fish Amphiprion melanopus on Guam. Z. Tierpsychol., 46: pp. 71-83.

19. Hoff FH (1996) Conditioning, spawning and rearing of fish with emphasis on marine clown fish. Dade city: Aquaculture Consultants, 212.

20. Tarlochan sing and VK Dey (2006) Trends in world ornamental fish trade. Souvenir, Ornamentals Kerala 2006, Dept. of Fisheries, Govt. of Kerala: 3-8.

21. Sale PF (1980) The ecology of fishes on coral reefs. Oceanogr Mar Biol Ann Rev 18: 367-421

22. Booth DJ, Wellington G (1998) Settlement preferences in coral-reef fishes: Effects on patterns of adult and juvenile distributions, individual fitness and population structure. Aust J Ecol 23:274-279

23. Jerkertamelander and Arjanrajasuriya(2008) Status of Coral reefs in south Asia: Bangladesh, Chagos, India, Maldives and Srilanka. Status of Coral Reefs of the World: 2008 
Citation: Uthaya Siva M, Selvakumar P, Sakthivel A (2014) Review on Influence of Climate Alterations on Corals and Associated Fishes for Indian Scenario. J Climatol Weather Forecasting 2: 114. doi:10.4172/2332-2594.1000114

Page 5 of 5

24. Pillai CSG (1996) "Coral reefs of India: Their Conservation and Management, in (Pillai CSG and Menon N.G. eds) "Marine Biodiversity, Conservation and Management," CMFRI, Cochin, India.

25. Bahuguna. A, S Nayak (1994) "Coral reef Mapping of Tamil Nadu using satellite data" SAC (ISRO), Ahmedabad, India.

26. Krishnamurthy K (1987) "The Gulf of Mannar Biosphere Reserve: Project document-5, Ministry of Environment \& Forests, Government of India.

27. Venketesan K.R (n.d). Gulf of Mannar Marine National Park (Proposed), unpublished report of the Chief wildlife warden, K.R Venketesan, Tamilnadu.

28. DOD \& SAC (1997) "Coral reef maps of India," Department of Ocean Development and Space Application Centre, Ahmedabad, India.

29. Pillai CSG (1975) An assessment of the effects of Environment and Human interference on the Coral Reefs of Palk Bay and the Gulf on Mannar, along the Indian Coast in Seafood export Journal Vol VIII No 12.

30. Pillai CSG (1986)"Recent Corals from South-East Coast of India" in PSBR
James (ed "Recent Advances in Marine Biology ', Today and Tomorrow Printers and Publishers, India.

31. Kumaraguru AK (1997) "Project title: Ecology of ornamental fishes of export value in the Gulf of Mannar", Project report for the period ending 31-1-97", School of energy, environment and natural resources, Madurai Kamaraj University, Madurai, sponsored by Department of ocean development, GOI.

32. Avar D (2005) Balikcılık Biyolojisive Populasyon Dinamiği. Nobel KitabeviYayınları: 332, Adana.

33. Çalta M ve Ural M (2001) AynaliSazan (Cyprinuscarpio L., 1758) yumurtalarininacilmasivelarvalarinyaamaoraniuzerinesuyun $\mathrm{pH}$ degerininetkisi. E.U. Su Urunleri Dergisi 18 (3-4): 319 - 324.

34. Graeme Macfadyen and Edward Allison (2009) Climate Change, Fisheries, Trade and Competitiveness: Understanding Impacts and Formulating Responses for Commonwealth Small States. Graeme Macfadyen, Poseidon Aquatic Resource Management Ltd, Geneva, Switzerland, in association with Dr. Edward Allison, World Fish Centre, Malaysia. 